\title{
GAMBARAN MUTU PELAYANAN KESEHATAN DI RUMAH SAKIT MELALUI PENERAPAN K3 OLEH PERAWAT
}

\author{
Elisa Claudia Simanjuntak / 181101114 \\ elclaudia02@gmail.com
}

\begin{abstract}
ABSTRAK
Latar Belakang : Potensi bahaya atau kecelakaan kerja di rumah sakit sangat tinggi. Dibutuhkan komitmen dan langkah manajemen untuk mengontrol seluruh tenaga kerja supaya terhindar dari potensi tersebut.

Tujuan : Tujuan penulisan kajian ini adalah untuk mengetahui gambaran mutu pelayanan kesehatan melalui penerapan K3 di rumah sakit.

Metode : Metode yang digunakan dalam kajian ini adalah literature review, yaitu dengan cara menganalisis, mengeksplorasi serta mengkaji bebas jurnal dan buku teks yang membahas tentang penerapan $\mathrm{K} 3$ di rumah sakit.

Hasil : Perlu diterapkan manajemen K3 untuk mengurangi angka kecelakaan kerja. Penerapan K3 juga dapat menunjang pelayanan kesehatan yang lebih baik bagi pasien.

Pembahasan : Pelaksanaan Keselamatan dan Kesehatan Kerja (K3) adalah salah satu bentuk upaya untuk menciptakan tempat kerja yang aman dan sehat, sehingga dapat mengurangi resiko kecelakaan kerja. Pelaksanaan K3 dapat menjadi gambaran mutu pelayanan yang baik di rumah sakit.
\end{abstract}

Kata Kunci : K3, Rumah Sakit, Perawat. 


\section{Latar Belakang}

Rumah sakit merupakan sarana kesehatan yang menyelenggarakan pelayanan kesehatan, tempat berkumpulnya orang sehat dan sakit. Resiko kemungkinan terjadinya gangguan kesehatan dan penularan penyakit di rumah sakit sangat tinggi. Banyak negara semakin meningkatkan kepeduliannya terhadap masalah Kesehatan dan Keselamatan Kerja (K3) yang dikaitkan dengan isu perlindungan tenaga kerja dan hak asasi manusia serta kepedulian terhadap lingkungan hidup. Hasil laporan National Safety Council (NSC) tahun 2008 menunjukan bahwa terjadinya kecelakaan kerja di rumah sakit $41 \%$ lebih besar dari industri lain. Kasus yang sering terjadi adalah tertusuk jarum, terkilir, sakit pinggang, tergores, terpotong, luka bakar, penyakit infeksi dan lain-lain.

Dari data tersebut, dapat disimpulkan bahwa potensi bahaya di rumah sakit sangat tinggi. Oleh karena itu, dibutuhkan komitmen dan langkah manajemen untuk mengontrol seluruh tenaga kerja supaya terhindar dari insiden yang tidak diinginkan. Penerapan K3 (Keselamatan dan Kesehatan Kerja) di rumah sakit menjadi sangat penting dalam rangka melindungi seluruh pekerja dari kecelakaan kerja dan penyakit.

\section{Tujuan}

Untuk mengetahui penerapan K3 (Keselamatan dan Kesehatan Kerja) di rumah sakit.

\section{Metode}

Metode yang digunakan dalam kajian ini adalah literature review, yaitu dengan cara menganalisis, mengeksplorasi serta mengkaji bebas jurnal dan buku teks yang membahas tentang penerapan K3 (Keselamatan dan Kesehatan Kerja) di rumah sakit. Referensi berupa jurnal dan buku teks yang digunakan adalah sebanyak 14 . Jurnal yang digunakan sebagai referensi dalam tulisan ini diterbitkan dalam kurun waktu 10 tahun terakhir.

\section{Hasil}

Kecelakaan kerja di rumah sakit $41 \%$ lebih besar dari industri lain. Hal itu terjadi karena belum maksimalnya penerapan K3 di rumah sakit. Oleh karena itu, perlu diterapkan manajemen K3 untuk mengurangi angka kecelakaan kerja tersebut. Penerapan K3 mampu menunjang pelayanan kesehatan yang lebih baik. 


\section{Pembahasan}

Pelaksanaan Keselamatan dan Kesehatan Kerja (K3) adalah salah satu bentuk upaya untuk menciptakan tempat kerja yang aman dan sehat, sehingga dapat mengurangi resiko kecelakaan kerja. Penerapan K3 di rumah sakit diharapkan mampu menunjang pelayanan kesehatan rumah sakit menjadi lebih baik. Selain itu , K3 dapat dijadikan media preventif dan proteksi diri dari penyakit penyakit akibat kerja dan kejadian kejadian yang tidak di inginkan di rumah sakit.

Setiap Rumah Sakit wajib melaksanakan pelayanan kesehatan dan keselamatan kerja sesuai yang tercantum pada pasal 23 dalam UndangUndang No. 36 tahun tahun 2009 tentang kesehatan dan Peraturan Menteri Tenaga Kerja dan Transmigrasi RI No.03/MEN/1982 tentang pelayanan kesehatan kerja.

Pelaksanaan K3 dapat menjadi gambaran mutu pelayanan yang baik di rumah sakit. Penerapan K3 dapat berjalan baik apabila ada komitemen dan kebijakan yang baik dari rumah sakit. Rumah sakit sebagai penyedia sarana harus memberikan pelayanan yang baik tidak hanya untuk pasien, tetapi juga karyawan dan tenaga kesehatan di dalamnya. Apabila K3 (Keselamatan dan Kesehatan Kerja) dari karyawan dan tenaga kesehatan di rumah sakit diperhatikan, tentu mutu pelayanan yang akan diberikan berkualitas.

\section{Penutup}

K3 (Keselamatan dan Kesehatan Kerja) merupakan tanggung jawab yang harus dipenuhi rumah sakit bagi para karyawannya. Penerapan K3 di rumah sakit mampu menunjang pelayanan kesehatan rumah sakit menjadi lebih baik.

\section{Referensi}

Ardi, S. \& Widodo H. (2018). Analisa Penerapan Budaya Perilaku Keselamatan dan Kesehatan Kerja di Rumah Sakit. Jurnal Fakultas Kesehatan Masyarakat. 12(1): 15-20.

Fadhila, N. dkk. (2017). Analisis Upaya Manajemen Rumah Sakit Dalam Penerapan Budaya Kesehatan dan Keselamatan Kerja (K3) Pasca Akreditasi pada Sebuah RSUD di Kabupaten Semarang. Jurnal Manajemen Kesehatan Indonesia. 5(1): 55-61. 
Ibrahim, H. dkk. (2017). Gambaran Penerapan Standar Manajemen Keselamatan dan Kesehatan Kerja Rumah Sakit di Rumah Sakit Umum Daerah Haji Makassar. Jurnal Ilmu Kesehatan Masyarakat. 9(2): 160-173.

Ivana, A. dkk. (2014). Analisa Komitmen Manajemen Rumah Sakit (RS) Terhadap Keselamatan Dan Kesehatan Kerja (K3) Pada RS Prima Medika Pemalang. Jurnal Kesehatan Masyarakat. 2(1): 35-41.

Mauliku, N. E. (2011). Kajian Analisis Penerapan Sistem Manajemen K3RS di Rumah Sakit Immanuel Bandung. Jurnal Kesehatan Kartika. 35-47.

Nazirah, R \& Yuswardi. (2017). Perilaku Perawat Dalam Penerapan Manajemen Kesehatan dan Keselamatan Kerja (K3) di Aceh. Jurnal Idea Nursing. 8(3).

Nurhidayanti, D. (2017). Pengaruh Pelaksaanaan Keselamatan dan Kesehatan Kerja Terhadap Kepuasan Kerja Perawat. JOM FISIP. 4(1): 1-10.

Putri, S. dkk. (2018). Pelaksanaan Keselamatan dan Kesehatan Kerja
Terhadap Kejadian Kecelakaan Kerja Perawat Rumah Sakit. Jurnal Endurance. 3(2): 271-277.

Rahayuningsih, P. W. \& Widodo H. (2011). Penerapan Manajemen Keselamatan dan Kesehatan Kerja (MK3) di Instalasi Gawat Darurat RSU PKU Muhammadiyah Yogyakarta. Jurnal Fakultas Kesehatan Masyarakat. 5(1): 1-67.

Salikunna, N. A. \& Vera D. (2011). Penerapan Sistem Manajemen Kesehatan dan Keselamatan Kerja di Rumah Sakit Bersalin Pertiwi Makassar. Jurnal Biocelebes. 5(1): 31-42.

Salmawati, L. dkk. (2015). Hubungan Penerapan Sistem Manajemen Keselamatan dan Kesehatan Kerja Dengan Motivasi Kerja dan Stres Kerja Pada Perawat di Rumah Sakit Umum Anutapura Palu. Jurnal Manajemen Pelayanan Kesehatan. 18(1): 4-6.

Simamora, R. H. (2019). Buku Ajar Pelaksanaan Identifikasi Pasien. UWAIS:Inspirasi Indonesia. 
Simamora, R. H. (2019).

Documentation of patient Identification into the Electronic System to improve the quality of nursing services. Internasional Journal of Scientific \& Technology Reasearch.

Simamora, R. H. (2019). The influence Of Training Handover based SBAR Communication for improving patients Safety. Indian journal of public Health Reserch \& Development. 